\title{
MASJID LAMA GANG BENGKOK SEBAGAI SIMBOL MULTIETNIS DI KOTA MEDAN
}

\author{
Raini Tanjung, Rudiansyah, Jessy Chen \\ Program Studi Sastra Cina Fakultas Ilmu Budaya \\ Universitas Sumatera Utara
}

\begin{abstract}
The title of this research is 'Lama Gang Bengkok Mosque As A Multiethnic Symbol In The City Of Medan'. The purpose of this study was to analyze the ornamental and symbolic forms of the Lama Gang Bengkok Mosque building, and explain the history of the Lama Gang Bengkok Mosque which was used as a multiethnic symbol in Medan City. The method used is a qualitative research method and described descriptively. The theory used in this study is the semiotic theory of Charles Sanders Peirce. Data was obtained through observation and interview techniques with several informants and people around. The results showed that this building became one of the multiethnic symbols of harmony between religious and cultured people from ancient times to the present, and can be seen from the form and symbolism of the Lama Gang Bengkok Mosque building, such as the forms and symbols of Malay, Chinese and Persian culture.
\end{abstract}

Key Words: Lama Gang Bengkok mosque; Ornaments; symbolis; Multi-Language; Medan City

\begin{abstract}
Abstrak; Judul penelitian ini adalah 'Masjid Geng Tua Bengkok Sebagai Simbol Multietnis Di Kota Medan'. Tujuan dari penelitian ini adalah untuk menganalisis bentuk-bentuk ornamen dan simbolis dari bangunan Masjid Lama Gang Bengkok, dan menjelaskan sejarah Masjid Bengkok Lama yang digunakan sebagai simbol multietnis di Kota Medan. Metode yang digunakan adalah metode penelitian kualitatif dan dideskripsikan secara deskriptif. Teori yang digunakan dalam penelitian ini adalah teori semiotika Charles Sanders Peirce. Data diperoleh melalui teknik observasi dan wawancara dengan beberapa informan dan orang-orang di sekitar. Hasil penelitian menunjukkan bahwa bangunan ini menjadi salah satu simbol multietnis harmoni antara umat beragama dan berbudaya dari zaman kuno hingga saat ini, dan dapat dilihat dari bentuk dan simbolisme bangunan Masjid Lama Gang Bengkok, seperti bentuk dan simbol Budaya Melayu, Cina, dan Persia.
\end{abstract}

Kata Kunci: Masjid Old Crooked Alley; Ornamen; simbolis; Banyak bahasa; Kota Medan.

\section{PENDAHULUAN}

Di Medan, ada satu peninggalan sejarah yang dapat ditelusuri menjadi bukti kedekatan hubungan Islam dengan Tionghoa, yakni sebuah bangunan masjid yang terletak di Jl. Masjid, Kelurahan Kesawan namanya Masjid Lama Gang Bengkok. Masjid Lama Gang Bengkok dibangun oleh saudagar Tionghoa, Tjong A Fie. Masjid ini pertama kali dibangun pada tahun 1.885 Masehi, namun renovasi pembangunannya selesai pada tahun 1.889 M. Masjid ini kemudian diserahkan Tjong A Fie kepada Kesultanan Deli, yakni pada masa pemerintahan Sultan Deli Makmum Arrasyid.

Keberadaan Masjid Lama Gang Bengkok salah satu bentuk multietnis antar suku dan umat beragama di Kota Medan. Untuk mengetahuinya, dengan melihat ornamen dan simbolis yang melekat pada bangunan masjid menampilkan ciri khas perpaduan Cina, Melayu, dan Persia. Bagian luar masjid bangunannya didominasi dengan warna kuning dan hijau yang merupakan simbol kebudayaan Melayu serta ukiran-ukiran kayu pada atap masjid dan plafon mesjid yang terdapat umbaiumbai yaitu semacam hiasan yang disebut "lebah bergantung". Ukiran ini terbuat dari kayu, berbentuk semacam tirai berwarna kuning, warna khas Melayu. Warna kuning serta ukiran-ukiran kayunya semakin memperindah tampilan dalam masjid, serta mendukung kekhusyukan. Ditambah dengan ciri khas Cina yakni berbentuk atap masjid yang mengecut dengan lengkungan di setiap sisinya. Bentuk dari atapnya menyerupai kelenteng. Dan terdapat empat tiang penyanggah berdiameter lingkaran $2,10 \mathrm{~m}$, dan uniknya tiang ini juga terdapat di museum Tjong A Fie yang terletak di Jalan A.Yani (daerah Kesawan) Medan. Kemudian juga ada Persia, salah satu simbolnya yaitu lingkaran awalan tanpa akhir yang ada di dekat plafon bagian dalam masjid. Dan ada juga Gapura dan 
Mimbar yang ada di dalam masjid (Hasil wawancara, 22 Januari 2019).

Masjid Lama Gang Bengkok sudah dua kali diikut sertakan pada festival masjidmasjid bersejarah se Indonesia yang dibangun pada zaman penjajahan Belanda atau sebelum merdeka. Festival pertama berlangsung di Jakarta pada tahun 2003 kegiatan itu dilaksanakan oleh Dewan Masjid Indonesia Pusat dengan maksud antara lain membuat buku sejarah dan menjadikan masjid-masjid bersejarah sebagai bagian dari kunjungan wisata rohani di Indonesia (Nasution, 2009:19).

Penelitian ini bertujuan untuk Menjelaskan sejarah Masjid Lama Gang Bengkok yang dijadikan simbol multietnis di kota Medan, dan Menganalisis makna ornamen dan makna simbolis pada bangunan Masjid Lama Gang Bengkok.

Oleh karena itu, diharapkan penelitian ini dapat memberikan masukan dan sumbangan pengetahuan bagi masyarakat, pemerintah dan diharapkan dapat dijadikan sebagai tambahan kepustakaan dan sumber referensi pada penulisan proposal, skripsi dan jurnal di Program Studi Sastra Cina Fakultas Ilmu Budaya Universitas Sumatera Utara.

\section{LANDASAN TEORI}

Dalam penelitian ini membutuhkan landasan teori yang mendasar, karena landasan teori menerapkan kerangka dasar sebuah penelitian. Landasan teori yang digunakan hendaknya mampu menjadi tumpukan seluruh pembahasan. Didalam penelitian ini landasan teori yang digunakan ialah Teori Semiotik.

Semiotika berasal dari bahasa Yunani semeion, yang berarti tanda atau sign dalam bahasa Inggris, Semiotika adalah ilmu yang mempelajari sistem tanda seperti kode, bahasa, kata, sinyal, gerak isyarat,lampu lalu lintas,bendera dan sebagainya. Semiotika (semiotics) adalah ilmu tentang tanda dan kode-kodenya serta penggunaanya dalam masyarakat (Piliang, 2003:21).

Charles Sanders Peirce (1839-1914 dalam Hoed, 2014:10) seorang ahli filsafat dan tokoh terkemuka dalam semiotika modern Amerika menegaskan bahwa manusia dapat berfikir dengan sarana tanda, dan berkomunikasi dengan sarana tanda. Tandatanda memungkinkan manusia berfikir, berhubungan dengan orang lain dan memberi makna pada apa yang ditampilkan oleh alam semesta. Teori Peirce ini telah menyempurnakan teori Saussure sebelumnya, dimana objek benar-benar mempresentasikan maknanya.

Peirce mengemukakan teori segitiga makna atau triangle meaning yang terdiri dari tiga elemen utama, yakni tanda (sign), objek, dan interpretant. Tanda adalah sesuatu yang berbentuk fisik yang dapat ditangkap oleh panca indera manusia dan merupakan sesuatu yang merujuk (merepresentasikan) hal lain di luar tanda itu sendiri. Tanda menurut Peirce terdiri dari:

1. Ikon

Ikon merupakan tanda yang memiliki "rupa". Sebagai mana yang telah ada wujud nyatanya. Penggambaran ikon ada dengan dua cara, yaitu ilustratif (sesuai bentuk asli) dan diagramatik (dalam bentuk penyederhanaan).

Contoh: pohon, gunung, daun, tempat sampah, buku, dsb.

2. Indeks

Indeks merupakan tanda yang menunjuk kepada sebuah arti, indeks sering juga disebut petunjuk.

Contoh: marka jalan, lampu lalu lintas, plang nama jalan, dsb.

3. Simbol

Simbol merupakan tanda yang bersifat mewakili sebuah hal yang lebih besar yang ada dibelakangnya. Simbol juga bisa menunjukkan arti yang telah disepakati bersama.

Contoh : logo perusahaan, simbol-simbol budaya dan keagamaan.

Hal yang terpenting dalam proses semiotika adalah bagaimana makna muncul dari sebuah tanda.

\section{METODE PENELITIAN}

Jenis metode penelitian yang digunakan adalah metode deskriptif dengan pendekatan kualitatif. Penelitian kualitatif merupakan jenis penelitian yang menghasilkan penemuan-penemuan yang tidak dapat dicapai dengan menggunakan prosedur statistik atau cara kuantifikasi lainnya. Penelitian kualitatif diharapkan mampu menghasilkan suatu uraian mendalam tentang ucapan, tulisan, dan tingkah laku yang dapat diamati dari suatu individu, 
kelompok, masyarakat (Afifuddin dan Saebeni, 2009:73). Sedangkan, Penelitian deskriptif yaitu penelitian yang menggambarkan dan melukiskan keadaan obyek penelitian pada saat sekarang sebagaimana adanya berdasarkan fakta-fakta. Penelitian ini merupakan usaha untuk mengungkapkan masalah atau keadaan atau peristiwa sebagaimana adanya sehingga hanya bersifat sebagai pengungkap fakta (Moleong, 2008:6).

Adapun data pada penelitian ini adalah data primer dan data sekunder. Data primer di dapat dari sumber informan yaitu individu atau perseorangan seperti hasil wawancara yang dilakukan oleh penelitian, data primer dalam penelitian ini adalah : catatan hasil wawancara, hasil observasi lapangan, dan data-data mengenai informan. Sedangkan data sekunder berupa sumber-sumber atau referensi tertulis yang berhubungan dengan permasalahan penelitian, data sekunder dalam penelitian ini adalah : buku, jurnal, dan hasil penelitian para ahli lain yang berhubungan dengan masalah penelitian guna lebih menambah pengertian dan wawasan penulis demi kesempurnaan akhir penelitian ini. Sumber data dalam penelitian ini didapat melalui observasi dan wawancara dengan informan mengenai sejarah dan simbol multietnis yang ada pada Masjid Lama Gang Bengkok.

Teknik pengumpulan data yang digunakan dalam penelitian ini adalah wawancara, observasi lapangan dan dokumentasi. Didalam wawancara terdapat beberapa unsur yang membangunnya, yakni terdiri dari pewawancara, informan atau yang diwawancara, dan materi wawancara (Bungin,2008:108). Wawancara dibagi menjadi dua tipe, yaitu:

1. Wawancara terstruktur yaitu daftar pertanyaan yang telah tersusun secara sistematis sehingga penelitian telah mengetahui dengan jelas pertanyaan apa yang akan diajukan oleh seorang narasumber nantinya. Alat-alat penunjang yang diperlukan dalam proses wawancara juga tersedia, seperti alat perekam suara, kamera dan lainnya. Dalam penelitian ini, penulis menggunakan wawancara secara terstruktur dengan meyiapkan daftar pertayaan yang sesuai dengan topik kajian.
2. Wawancara tidak terstruktur yaitu wawancara yang daftar pertanyaannya tidak disusun dan biasanya tanpa ada daftar pertanyaan. Karena peneliti hanya sebatas menanyakan poin-poin dari garis besar sesuai topik kajian. Disela-sela wawancara yang terstruktur, penulis juga menyelipkan pertanyaan-pertanyaan secara langsung tanpa ada di dalam daftar pertanyaan.

Observasi diartikan sebagai pengamatan dan pencatatan secara sistematik terhadap gejala yang tampak pada objek penelitian, menurut Sutrisno Hadi (dalam Andi, 2010:27). Observasi awal yang penulis lakukan yaitu di Jln. Masjid, Kelurahan Kesawan Kecamatan Medan Barat, Kota Medan Sumatera Utara-Indonesia. Setelah itu, observasi kedua penulis lakukan yaitu ke Kediaman Rumah Kaptan Tjong A Fie di Jl. Jendral Ahmad Yani, Kesawan, Medan.Dokumentasi digunakan untuk mendapatkan keterangan dan penerangan pengetahuan serta bukti penelitian (I Gusti, 1997:73). Dalam hal ini penulis akan menyimpan data yang terkait objek kajian akan disimpan dan menjadi dokumentasi dengan menggunakan alat perekam dan kamera untuk mengambil foto. Metode analisis data yang dipakai penulis berupa analisis deskriptif dengan pendekatan kualitatif. Analisis deskriptif yang dimaksud berupa kata-kata dari penjelasan yang didapat melalui kejadian lapangan. Analisis digunakan untuk memahami hubungan dan konsep dalam data sehingga hipotesis dapat dikembangkan dan dievaluasi. Teknik analisis data ini dengan metode pengumpulan data, seperti data sekunder yag berupa kepustakaan bahan bacaan, dokumentasi, wawancara dan pengamatan. Dalam penelitian ini, penulis menganalisis "Masjid Lama Gang Bengkok Sebagai Multietnis Di Kota Medan" dengan menggunakan teori Semiotik yang dikemukakan oleh Charles Sanders Peirce. Hasil analisis data dalam penelitian ini disajikan dengan menggunakan metode penyajian sesuai dengan topik pembahasan yaitu menunjukkan bentuk struktur dan ornamen, bentuk simbol pada bangunan masjid dan alasan dijadikannya Masjid Lama Gang Bengkok sebagai simbol multietnis di kota Medan dengan menggunakan kata-kata secara informal. Penyajian hasil analisis data dengan 
menggunakan kata-kata yang biasa (Sudaryanto, 1993:145).

\section{HASIL DAN PEMBAHASAN}

\section{Gambaran Umum Kota Medan}

Kota Medan merupakan kota terbesar ketiga di Indonesia setelah Jakarta dan Surabaya, serta kota terbesar di luar Pulau Jawa. Kota Medan merupakan pintu gerbang wilayah Indonesia bagian barat dengan keberadaan Pelabuhan Belawan dan Bandar Udara Internasional Kuala Namu yang merupakan bandara terbesar kedua di Indonesia. Akses dari pusat kota menuju pelabuhan dan bandara dilengkapi oleh jalan tol dan kreta api. Medan adalah kota pertama di Indonesia yang mengintegrasikan bandara dengan kereta api. Berbatasan dengan Selat Malaka menjadikan Medan kota perdagangan, industri, dan bisnis yang sangat penting di Indonesia.

\section{Sekilas Perkembangan Bangunan Tiongkok di Kota Medan}

Sejarah bangunan Tiongkok dikembangkan secara lengkap sebelum Dinasti Man Zhu pada tahun 2000 SM. Karena mata pencaharian penduduk sangat tergantung pada produksi pertanian, tingkat perekonomiannya menjadi sangat rendah, karenanya konstruksi kayu, walaupun mudah terbakar, menjadi metode bangunan yang populer dan banyak dipakai selama lebih dari 20 abad. Rangka kayu Tiongkok tidak hanya berfungsi secara efektif, tetapi juga memperlihatkan keanggunan. Karakter arsitektur Tiongkok terlihat pada sistem struktur bangunan, bentuk atap, dan penggunaan warna. Karakter arsitektur Tiongkok ini terlihat pada bangunan Masjid Lama Gang Bengkok yang berada di wilayah Kecamatan Medan Barat.

\section{Sejarah Masjid Lama Gang Bengkok} Masjid Lama Gang Bengkok punya keunikan tersendiri karena dibanguan bersamaan dengan awal perkembangan Kota Medan. Tidak hanya itu saja, masjid ini juga terdengar unik dari sebutan namanya yang tidak memiliki nama arab pada umumnya. Yang mana nama masjid ini, diambil dari sebutan nama tempatnya. Dulunya didepan masjid ini terdapat sebuah gang kecil yang bengkok. Sehingga masyarakat setempat menamai masjid ini menjadi Masjid Lama Gang Bengkok. Masjid Lama Gang Bengkok merupakan masjid tertua ke 2 di Sumatera Utara yang didirikan pada tahun 1874-1885 M, setelah masjid Osmani yang dibangun pada tahun 1854 M dan Masjid Raya Al-Mashun yang dibangun tahun 1909. Masjid Lama Gang Bengkok dibangun di atas tanah seluas $1.600 \mathrm{~m}$ (40 m x 40 m), wakaf dari Haji Muhammad Ali yang lebih dikenal dengan nama panggilan Datuk Kesawan. Sebutan Datuk Kesawan karena ia seorang pengusaha kaya raya yang telah lama tinggal didaerah Kesawan. Seluruh biaya pembangunannya ditanggung oleh Tjong A Fie (1860-1921) seorang saudagar Tionghoa dari daratan China yang kemudian hijrah ke Kota Medan di awal abad ke 19. Peletakan batu pertama pembangunan masjid ini dilakukan sendiri oleh Sultan Makmum Alrasyid Perkasa Alam (1873-1924), Sultan Deli ke-9 yang berkuasa saat ini. Setelah selesai pembangunan Masjid Lama Gang Bengkok pada tahun 1890, masjid ini diserahkan kepada Sultan Deli Makmum Alrasyid Perkasa Alam yang menjadi Sultan Deli pada saat itu. Untuk pengelolaan masjid ini, selanjutnya dipercayakan kepada Syeikh HM Yakub sebagai Nazir pertama dan juga diberi tugas untuk menjadi Imam di Masjid Lama Gang Bengkok ini.

\section{Makna Ornamen Pada Masjid Lama Gang Bengkok \\ Menurut Kamus Besar Bahasa} Indonesia (KBBI, 2007), makna adalah sebuah arti atau maksud, denotasi makna kata atau kelompok kata yang didasarkan atas hubungan lugas antara satuan dan wujud diluar bahasa, seperti orang, benda, tempat, sifat proses dan kegiatan. Sedangkan, Ornamen artinya hiasan yang diatur dengan baik dalam bidang maupun diluar bidang tertentu guna mencapai suatu tujuan keindahan.

Makna ornamen yang terdapat pada Masjid Lama Gang Bengkok dapat di lihat melalui penggunaan warna, motif atau bentuk dari ornamen pada bangunan Masjid Lama Gang Bengkok. Dibawah ini, penulis akan jelaskan makna ornamen yang terdapat pada Masjid Lama Gang Bengkok.

\section{Makna Ornamen Cina}


Bangunan yang dihiasi dengan ornamen-ornamen khas Cina biasanya adalah kelenteng (rumah ibadah masyarakat Tiongkok/Cina), ada pula yang diaplikasikan pada masjid dan rumah-rumah masyarakat Cina itu sendiri. Peneliti mengamati terdapat beberapa masjid yang menggunakan ornament Cina pada bangunannya,salah satunya adalah Masjid Lama GangBengkok yang menggunakan

nya pada bagian empat tiang penyanggah yang ada di dalam masjid dan penggunaan warna khas Cina pada atap masjid. Peletakan ornamen umumnya pada dinding, atap, pilar, pintu dan elemen interior lainnya sesuai dengan sifat dan maknanya. Secara umum jenis ornamen Cina yang biasa digunakan terdiri dari motif fauna (hewan), motif flora, fenomena alam, lagenda, dan geometris.

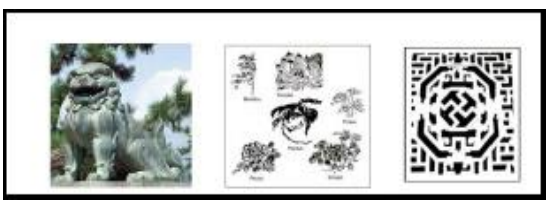

Gambar 1 Ornamen Arsitektur Cina Sumber : Moedjiono, 2011

Ornamen Cina yang terdapat pada Masjid Lama Gang Bengkok yaitu bermotif flora. Bentuk ornamen bagian atas tiang yaitu bermotif bunga dan daun. Ornamen ini mengandung makna tentang unsur-unsur kehidupan dan kekuatan. Penggunaan warna hijau pada atap masjid yang maknanya untuk kedamaian dan keabadian, dan warna keemasan pada tiang penyanggah melambang makna kerajaan, kekukuhan, dan kekayaan (Chinese Philosophy).

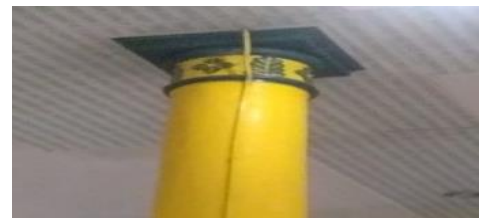

Gambar 2 Ornamen Tiang yang bermotif Flora seperti bunga dan daun

Sumber : Raini Tanjung, 2019

\section{Makna Ornamen Melayu}

Menurut Kartini (2014) adapun jenis-jenis ornamen Melayu berdasarkan bentuknya dibagi atas : motif flora (tumbuh-tumbuhan), motif fauna (hewan), motif alam, motif kaligrafi, dan motif beraneka ragam.

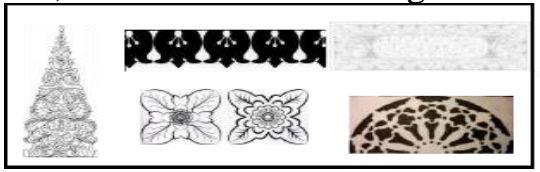

Gambar 3 Ornamen Arsitektur Melayu Sumber : Ayu Kartini, 2014

Ornamen Melayu yang terdapat pada Masjid Lama Gang Bengkok yaitu bermotif fauna (hewan). Bentuk ornamen bagian umbai-umbai nya seperti lebah bergantung. Ukiran ini dibuat dari kayu, berbentuk semacam tirai berwarna kuning. Ukiran ini melambangkan manisnya kehidupan rumah tangga, raja berkorban dan tidak mementingkan diri sendiri. Penggunaan warna khas Melayu pada Masjid Lama Gang Bengkok berwarna kuning, hijau dan putih. Kuning bermakna kemegahan dan kesuburan serta kemakmuran dalam hidup. Umumnya, sering digunakan pada ornamen bangunan Istana, Masjid, maupun rumah penduduk Melayu. Warna Hijau digunakan untuk identik bangunan bernuansa Islam. Umumnya digunakan pada Masjid. Putih melambangkan kesucian, dalam menjalankan tugas sangat dibutuhkan kejujuran agar terhindar dari kekerasan. Umumnya warna putih digunakan sebagai warna dasar pada tembok atau dinding rumah.

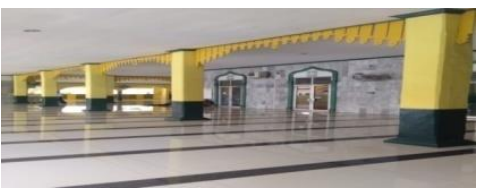

Gambar 4 Hiasan Ornamen Melayu bermotif "Lebah Bergantung".

Sumber : Raini Tanjung, 2019

\section{Makna Ornamen Persia}

Ornamen yang terdapat pada Arsitektur Persia terdiri dari geometris, kaligrafi, tumbuhan, dan muqarnas. Bentuk ornamen geometris nya seperti lingkaran, cincin, kurva, segi-tiga, segi banyak, yang saling dijalin atau digabungkan.

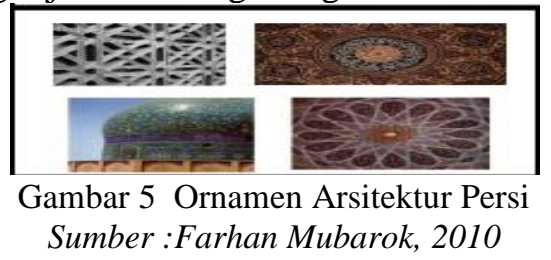

Ornamen Persia bagian atas dinding Masjid 
Lama Gang Bengkok bermotif lingkaran. Gelombang-gelombang berupa garis-garis yang diberi lengkung diulang-ulang saling berjalin hingga ujung-ujungnya bertemu dengan pangkalnya, menghasilkan kesamaan dan memancarkan gerakan berirama seperti berbentuk ornamen Itik sekawan atau bisa juga disebut sebagai awalan tanpa akhir. Makna ornamen itik sekawan ini menggambarkan tingkah laku hewan Itik yang selalu berjalan beriringan ketika petang hari akan pulang ke kandang. Tingkah laku berjalan beriringan serasi, bersahabat, kompak, bersama-sama, menjadi contoh bagi manusia akan arti kehidupan. Hal ini pun lalu digambarkan dan menjadi suatu corak motif untuk tenun, tekat, ukir, dan songket dengan nama Motif Itik Sekawan.Penggunaan warna pada dinding masjid dan dinding menara menggunakan warna pasir.

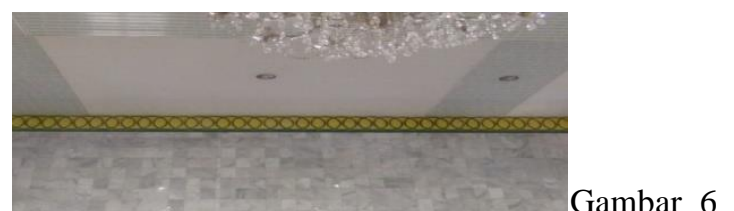

Ornamen Persi pada langit - langit dinding bermotif "Itik Sekawan (awalan tanpa akhir)"

Sumber : Raini Tanjung, 2019
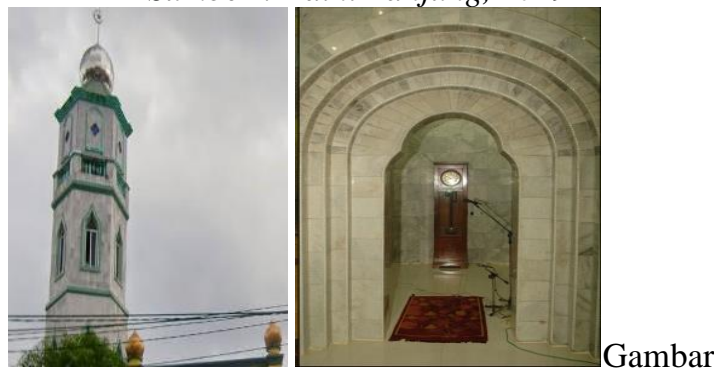

7 Warna pasir pada dinding masjid Sumber : Raini Tanjung, 2019

\section{Tiang Penyangga}

Salah satu simbolis pada bangunan Masjid Lama Gang Bengkok yaitu terdapat empat buah tiang penyangga berdiameter lingkaran 2,10 meter dan tingginya 3,40 meter, yang mana keempat tiang penyanggah ini sama persis dengan tiang penyanggah yang ada pada kediaman rumah Tjong A Fie. Menurut pendapat informan, simbolis yang terdapat pada tiang penyanggah ini dilihat dari air, api, kayu dan tanah (filosofi Tiongkok).

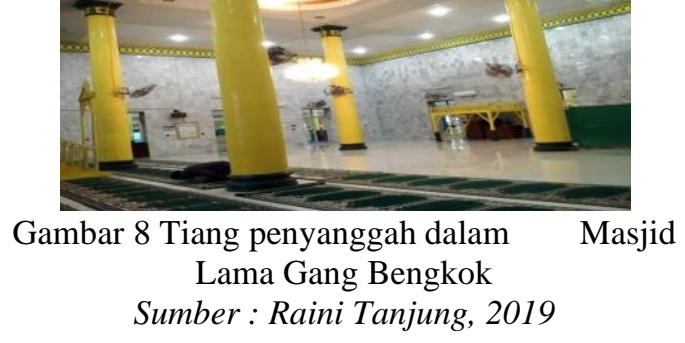

A. Air

Air mempunyai kemampuan besar untuk berkomunikasi dan melaksanakan ide-ide yang ada dengan cara mempengaruhi orang lain untuk mewujudkannya. Mereka mencapai keinginannya dengan menunjukkan dan memanfaatkan bakat serta kemampuan orang lain. Mereka akan lebih dikendalikan oleh perasaan, namun hal ini akan tergantung dengan shio yang mereka miliki. Meskipun demikian, pendekatan mereka tidak pernah membuat orang lain merasa telah dimanfaatkan. Mereka memiliki bakat dan naluri yang tinggi dalam menebak hal-hal yang akan menjadi penting dan berpotensi di masa depan. Sesuai dengan karakteristik Air, mereka menyingkirkan penghalang terbesar dengan tenang disertai usaha yang terus-menerus atau konsisten.

\section{B. Api}

Unsur Api akan menunjukkan bakatbakat kepemimpinan yang tinggi, cepat mengambil keputusan dan percaya pada diri sendiri. Mereka adalah motivator yang baik dan mampu mewujudkan ide-idenya, karena mereka lebih agresif dibanding orang lain yang lahir di bawah shio yang sama. Mereka menggemari petualangan dan inovasi, akibatnya mereka selalu siap melaksanakan ide- ide baru dan akan berusaha mendominasi orang lain dengan kreatifitas, keaslian serta kemampuannya dalam menanggung resiko.

\section{Kayu}

Unsur Kayu melambangkan moral yang tinggi dan rasa percaya diri yang tinggi. Mereka berbakat dalam membagi dan memisahkan berbagai masalah dalam kategori yang benar agar sesuai dengan tujuan. Sifat maju dan murah hati yang mereka miliki memungkinkan mereka dalam melaksanakan proyek-proyek besar, perkembangan jangka panjang dan rencana atau penelitian ilmiah 
yang strategis. Minat mereka juga sangat luas dan beragam, dan kemampuan untuk bekerja sama akan mendukung mereka untuk melakukan hal-hal dalam skala besar.

\section{Tanah}

Unsur tanah lebih memperhatikan tujuan-tujuan praktis dari pada impian. Mereka memiliki pemikiran yang luar biasa dan menyukai tujuan yang nyata. Dengan visi mereka serta kemampuan untuk berorganisasi, mereka adalah perencana dan pengelola yang efektif. Mereka akan menggunakan segala potensi yang mereka temukan secara optimal dan cenderung bijaksana dan teliti dalam masalah keuangan. Mereka cerdas dan obyektif dalam menuntun orang lain untuk mewujudkan tujuan yang telah direncanakan dengan matang. Pada umumnya mereka adalah orang-orang yang serius dan metodis dalam cara kerja dan dapat mengorganisasikan dan menjalankan segala jenis bisnis yang menuntut pengelolaan yang tegas.

\section{Ukiran Lebah Bergantung}

Lebah Bergantung, simbolis bangunan melayu yang menghiasi dinding Masjid Lama Gang Bengkok. Hiasan ini pada setiap bidangnya memiliki 21 ukiran yang secara simetris dijejerkan kekiri dan kekanan masing-masing 10 buah, di tengahnya di batasi dengan ukuran yang agak lebih panjang. Ukiran ini dicat warna kuning sebagai khas warna melayu. Di sekeliling teras masjid ini ada 17 ukiran lebah bergantung. Makna simbolis Ukiran "Lebah Bergantung" ini melambangkan manisnya kehidupan rumah tangga, raja berkorban dan tidak mementingkan diri sendiri.

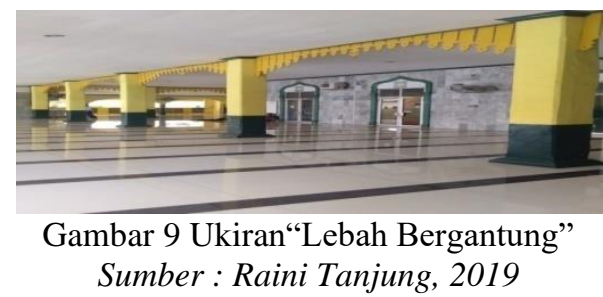

\section{Mimbar Khatib}

Mimbar di ruang salat utama berukuran tinggi $3,30 \mathrm{~m}$ (depan) $\times 5,15 \mathrm{~m}$ (belakang) x 3,50 m (panjang) x 0,90 m (lebar). Mimbar ini memiliki 13 buah tangga (jenjang) yang masing-masing tangga berukuran tinggi
$23 \mathrm{~cm}$. Di sisi kiri kanan mimbar dibuat kotak bersusun, dua buah, masing-masing berukuran $94 \mathrm{~cm}$ x $57 \mathrm{~cm}$. Mimbar ini terbuat dari kayu, yang mana kondisinya masih tetap kokoh hingga kini masih digunakan untuk khatib berkhutbah di hari Jumat dan hari-hari Raya Idul Fitri dan Idul Adha. Bentuk mimbar terbuka di bagian depan mimbar dengan warna kuning keemasan didesain khas, anak tangga berada di depan, sehingga khatib pada saat berdiri di mimbar tampak jelas terlihat oleh jamaah. Berbeda dengan mimbar yang terdapat di masjid-masjid masa kini. Bagian depannya tertutup sehingga keberadaan khatib tidak tampak oleh jamaah. Disamping kiri dan kanan mimbar dipasang bendera berwarna hijau, di tengahnya terdapat bulan sabit dan bintang berwarna kuning. Warna hijau dimaknai sebagai lambang kesuburan dan identik atau sama dengan warna sorban Nabi juga berwarnai hijau. Bendera dimaknai sebagai panji-panji kebesaran dan lambang kejayaan. Penggunaan lambang ini adalah sebagai lambang agama Islam dalam menegakkan ajarannya serta penyebarannya ditengah umat manusia dengan pendekatan persaudaraan. Bentuk bulan sabit melambangkan awal pertumbuhan agama Islam yang kemudian akan menjadi bulan purnama sebagai gambaran pengembangan Islam yang lebih luas. Sedang bintang kecil (di tengah bendera) melambangkan harapan suci, penuh dengan keberkahan, kecemerlangan di mana agama Islam akan memberikan kehidupan yang bahagia dunia dan akhirat. Mimbar Khatib ini diadopsi dari masjid-masjid Timur Tengah. Mimbar ini merupakan salah satu simbolis bangunan Persia.

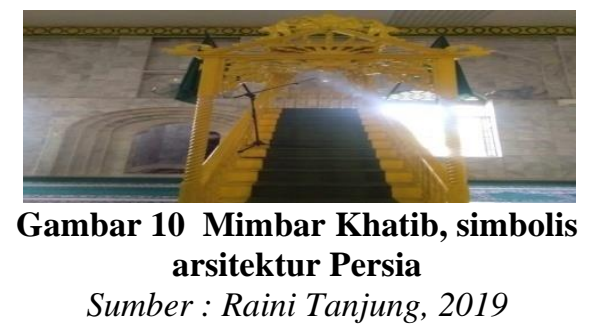

\section{Atap Masjid Lama Gang Bengkok}

Bentuk atap Masjid Lama Gang Bengkok berbentuk melengkung puncaknya mirip payung yang di maknai sebagai "mengayomi". Atap dari masjid ini sama dengan atap klenteng. Tidak pada umumnya, 
masjid-masjid biasanya menggunakan bentuk Kubah di atas atap masjid. Beda dengan halnya Masjid Lama Gang Bengkok, atap masjid ini sama sekali tidak ada berbentuk Kubah. Kecuali atap menara nya yang berbentuk kubah.

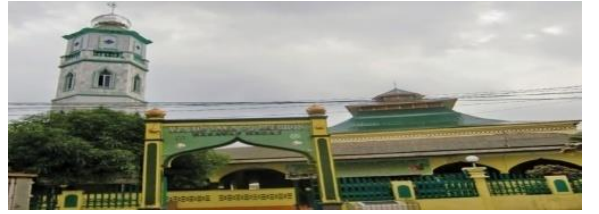

Gambar 11 Atap Masjid Lama Gang Bengkok Sumber : Raini Tanjung, 2019

\section{BIOGRAFI PENDIRI MASJID}

Menurut H. Muklis Tanjung, Masjid Lama Gang Bengkok didirikan atas ide atau gagasan 4 orang yaitu Datuk M. Ali sebagai agnia, Syeikh Muh Yacub pemuka Mandailing sebagai ulama, Mufti Syekh Hasan Maksum dan dana dari Tjong A Fie. Kecuali mufti Syekh Hasan Maksum, nama-nama tersebut diabadikan pada batu peringatan yang diletakkan di depan Masjid Lama Gang Bengkok. Keempat pendiri ini, melambangkan kerukunan di saat pertumbuhan Kota Medan dalam persaingan ekonomi. Etnis Mandailing orang pedagang di Kesawan, Muh. Ali, orag Melayu Agnia di Kesawan, Tjong A Fie pengusaha, sedang Mufti memberi fatwa untuk membolehkan membangun masjid di Kesawan. Dengan dibangunnya masjid ini masing-masing pihak merasa puas. Etnis Melayu (umat Islam) memiliki bangunan masjid baru sebagai tempat ibadah sedangkan etnis Cina merasa puas karena dengan arsitektur masjid yang didominasi arsitektur Cina itu membuktikan bahwa mereka pun mempunyai saham dalam proses menciptakan kerukunan hidup umat beragama.

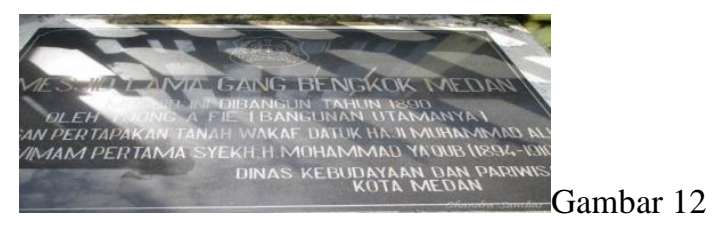

Batu Peringatan

Sumber : Raini Tanjung, 2019

\section{SIMPULAN DAN SARAN}

Berdasarkan hasil analisis data penelitian Masjid Lama Gang Bengkok sebagai simbol multietnis di Kota Medan dapat disimpulkan bahwa, pada bangunan Masjid Lama Gang Bengkok terdapat unsur-unsur arsitektur budaya Melayu, Cina, dan Persia. Masjid Lama Gang Bengkok merupakan salah satu bangunan simbol multietnis yang ada di daerha Kesawan Kota Medan. Bentuk arsitektur Melayu mendominasi pada bangunan berupa Ornamen dan penggunaan warna, sedangkan bentuk arsitektur Cina mendominasi pada bangunan berupa ornamen pada tiang penyanggah, bentuk atap dan penggunaan warna. Dan bentuk arsitektur Persia mendominasi pada bangunan berupa Ornamen, bentuk gapura,warna dinding dan barang-barang peninggalan yang memiliki makna simbolis. Bangunan masjid ini menjadi bukti bahwa arsitektur Tiongkok dapat di sandingkan dengan arsitektur Melayu dan Persia, sekaligus bukti kerukunan antar budaya dan agama dari dulu hingga sekarang. Oleh karena itu sangat disayangkan jika bangunan hasil akulturasi yang ada di Kota Medan seperti ini masih kurang dilestarikan sebagaimana mestinya.

Disamping itu, saran terhadap bangunan Masjid Lama Gang Bengkok juga terangkum dalam beberapa bagian berikut, yaitu perlunya kerjasama yang lebih efektif dan berkesinambungan dari pihak Pemerintah (Dinas Pariwisata dan Budaya Kota Medan), Masyarakat, serta kenaziran Masjid Lama Gang Bengkok untuk dapat menjaga dan merawat serta dapat menarik wisatawan mengunjungi Masjid Lama Gang Bengkok dengan cara menyebarkan informasi ke pada masyarakat luas lewat media sosial. Selain itu, perlu adanya usaha penelitian selanjutnya untuk menemukan potensi-potensi yang dapat diangkat dan menjadi nilai tambah bagi Masjid Lama Gang Bengkok sebagai objek tujuan wisata sejarah, untuk itu diperlukan kerjasama antara peneliti dengan pihak kenaziran Masjid Lama Gang Bengkok .

Untuk mendukung potensi diperlukan adanya pelayanan dan kebutuhan bagi para wisatawan atau jamaah yang mengunjungi Masjid Lama Gang Bengkok, seperti menceritakan mengenai sejarah Masjid Lama Gang Bengkok dan makna-makna simbolis yang terdapat dari bangunan Masjid Lama Gang Bengkok dengan cara peningkatan aksesbilitas yang dapat memudahkan wisatawan untuk mendapatkan keterangan 
mengenai Masjid Lama Gang Bengkok, baik dalam bentuk katalog serta buku sejarah Masjid Lama Gang Bengkok, agar para pengujung bisa mendapatkan informasi lebih mendalam.

\section{REFERENSI}

Afifuddin, B. \& Saebeni, A. 2009. Metologi Penelitian Kualitatif. Bandung: Pustaka Setia.

Andi, P. 2010. Menguasai Teknik-Teknik Koleksi Data Penelitian Kualitatif (Bimbingan dan Pelatihan lengkap Serba Guna). Yogyakarta: Diva Press.

Bungin, Burhan. 2008. Analisis Data Penelitian Kualitatif. Jakarta: Raja Grafindo Persada.

Handinoto. 1998. Arsitektur Gaya Indo Eropa Tahun 1920an di Indonesia. Surabaya: Universitas Kristen Petra.

Koh, Vincent. 2011. I Ching Wisdom Revealed. Jakarta: Kompas Gramedia.

Moleong, Lexy J. 2008. Metode Penelitian Kualitatif. Bandung: Remaja Roskarya.

Nasution, Sazli. 2009. Sejarah Singkat Mesjid Lama Gang Bengkok Medan. Medan: Pengurus Badan Kenaziran Masjid Lama Gang Bengkok Kesawan Medan.

Piliang, Y. A. 2003. Hipersemiotika (Tafsir Cultural Studies Atas Matinya Makna). Bandung: Jalasutra.

Sudaryanto. 1993. Metode \& Aneka Teknik Analisis Data (Pengantar Penelitian Wahana Kebudayaan Secara Linguistik). Yogyakarta: Duta Wacana University Press.

Kartini, Ayu. 2014. Analisis Penerapan Ornamen Bernuansa Melayu Ditinjau dari Bentuk dan Warna di kota Medan. Medan: Universitas Negeri Medan.

Rudiansyah. 2014. Tipologi dan Makna Simbolis Rumah Tjong A Fie Di Kota
Medan. Skripsi USU. 